tinnitus by amplifying desirable environmental sounds. ${ }^{2}$ Without counselling and continued support, however, hearing aids alone are not effective. ${ }^{3}$ Furthermore, despite anecdotal evidence, controlled studies of tinnitus maskers have failed to show that they are better than placebo. ${ }^{3}$

Intravenous lignocaine results in the disappearance or amelioration of tinnitus, but no oral antiarrhythmic or anticonvulsant drugs have been found to be of benefit. Formal psychiatric assessment, with appropriate drug treatment, works in some patients. Benzodiazepines have been the drugs of choice in anxious patients, but they may make a depressed patient with tinnitus worse. In view of the association between tinnitus and depressive illness, treatment with tricyclic antidepressants has been proposed: nortriptyline is effective, although trimipramine is not. ${ }^{3}$

Rarely, surgery for arterial stenoses, glomus jugulare tumours, and arteriovenous malformations is indicated, but there is no evidence that destructive labyrinthectomies or eighth nerve sections are of benefit. It is much better for patients with troublesome tinnitus to be investigated for a cause and managed by someone with a positive attitude towards the condition, prepared to give an informed explanation and appropriate psychological or psychiatric support.

LINDA M LUXON

Professor of audiological medicine

Institute of Laryngology and Otology,

London WC1X 8EE

\footnotetext{
I Heller MF, Bergman M. Tinnitus aurium in normally hearing persons. Ann Otol Rhinol Laryngol 1993;62:73-83.

Coles RRA. Tinnitus and its management. In: Stephens SDG, ed. Scott Brown's otolaryngology. 5th ed. Vol 2. Audiology. London: Butterworths, 1987:368-414.

Hinchcliffe R, King PF. Medicolegal aspects of tinnitus (I). F Audiol Med 1992;1:38-58.

4 Luxon LM. Disorders of hearing. In: Asbury AK, McKhann GM, McDonald WI, eds. Diseases of the nervous system. Philadelphia: W B Saunders, 1987:544-60.
the

5 Hallam R, Rachmann S, Hinchcliffe R. Psychological aspects of tinnitus. In: Rachmann S, ed. Contributions to medical psychology. Oxford: Pergamon Press, 1984:31-50.

6 McKenna L, Hallam RS, Hinchcliffe R. The prevalence of psychological disturbance in neurootology outpatients. Clin Otolaryngol 1991;16:452-6.

7 Hawthorne M, O'Connors S. The psychological side of tinnitus. BMf 1987;294:1441-2.

8 Barr T. Enquiry into the effects of loud sounds upon the hearing of boilermakers and others who work amid noisy surroundings. Proceedings of the Glasgow Philosophical Society 1886;17:223-39. Hinchcliffe R, King PF. Medicolegal aspects of tinnitus. II. Features of tinnitus in various disorders. Fournal of Audiological Medicine 1992;1:59-78.

10 Hoke M, Feldmann H, Pantev C, Lutkenhoner B, Lehnertz K. Objective evidence of tinnitus in

audis J Sou 1992;1:30-7.
}

\title{
Sickle cell disease: the case for coordinated information
}

\section{Currently little is known of its epidemiology in Britain}

Despite an estimated 5000 people with sickle cell disease in Britain, living mainly in large cities, few reliable data exist on its incidence at birth and its natural course. ${ }^{1-3}$ Lack of information has hindered the establishment of a comprehensive national policy to guide the development and evaluation of services for sickle cell disease. ${ }^{45}$

The problems are exemplified by the issues surrounding neonatal screening. Estimates of the number of babies affected vary widely from 75 to 300 a year. ${ }^{12}$ Early diagnosis, combined with prophylaxis against pneumococcal infection, parental education, and adequate follow up reduce early childhood mortality in sickle cell disease. ${ }^{67}$ This has led to calls for the introduction of a comprehensive neonatal screening programme in Britain. ${ }^{8}$

Locally, decisions on whether and how to screen neonates for sickle cell disease have largely depended on the commitment of individual people, with little central support in terms of policy direction or resources. This has resulted in differing approaches nationwide; in contrast, the need for a national neonatal screening programme for phenylketonuria, which detects about 90 affected infants a year, is widely recognised. ${ }^{9}$

Infants with sickle cell disease are born mainly in inner city areas with large populations at risk. Universal screening may be appropriate here, whereas selective screening may be more appropriate in districts with a low proportion of infants at risk. ${ }^{11}$ Despite this some districts that might most cost effectively adopt universal screening operate selective screening and vice versa. To facilitate a consistent approach to screening across the country, assessment of the cost effectiveness of different approaches to screening in relation to the proportion of the population at risk is needed. Account also needs to be taken of the coverage of screening programmes: selective screening may miss up to $15 \%$ of infants at risk. ${ }^{12}$ Both selective and universal programmes will succeed only if the organisation and resources are available to ensure adequate follow up of affected children. ${ }^{213}$
Inconsistent policies between adjoining districts with large populations at risk result in failure to detect all affected infants. For example, infants born in a district with a policy to screen resident infants six to 10 days after birth but living in a district that practises cord blood screening will remain untested. Several health authorities have already made substantial out of court settlements for failing to diagnose sickle cell disease neonatally or antenatally.

Deficiencies in our knowledge of the number and distribution of affected births are mirrored by ignorance of the natural course of sickle cell disease in Britain. Few figures on mortality or survival are available. ${ }^{3}$ This has been highlighted by the recent debate surrounding the use of bone marrow transplantation in sickle cell disease. ${ }^{14}$ Without accurate information on the long term outlook for patients who receive comprehensive supportive care it is difficult to judge the role of bone marrow transplantation, which offers a possible cure but carries an estimated $5-10 \%$ risk of death and serious morbidity related to the procedure. This dilemma is likely to recur as other new approaches to the treatment of sickle cell disease become available.

These issues show the need for a clear policy on sickle cell disease in Britain based on reliable data. We need coordinated information to define the size of the affected population and the natural course of the disease if we hope to develop and evaluate health services for this group of patients. ${ }^{15}$ Long term follow up of affected infants identified by neonatal screening could provide the foundation for a national cohort study along the lines of that funded by the Medical Research Council and the Overseas Development Administration in Jamaica, which, in a different setting, has provided invaluable information on the epidemiology of the disease. ${ }^{16}$

There is now an opportunity to address these issues. The Standing Medical Advisory Committee is due to report soon on the care of patients with haemoglobinopathies, and this should help to develop a national policy for sickle cell disease. A government that is committed to addressing the health 
needs of ethnic minorities will, we hope, support the committee's report with adequate resources. ${ }^{17}$

ALLISON STREETLY

Senior registrar in public health medicine

Department of Public Health Medicine,

United Medical and Dental Schools,

St Thomas's Hospital,

London SE1 7EH

MOIRA DICK

Consultant community paediatrician

West Lambeth Community Care NHS Trust

London SW9 9NU

MARK LAYTON

Senior lecturer

Department of Haematological Medicine

King's College Hospital,

London, SE5 9RS

1 World Health Organisation Regional Office for Europe. The haemoglobinopathies in Europe: combined report of two meetings. Copenhagen: WHO Regional Office for Europe, 1988

2 Streetly A. Health care needs for sickle cell disease in West Lambeth district. London: Faculty of Public Health Medicine, 1992. (Part II submission for Diploma of Membership of the Faculty of Public Health Medicine.
3 Gray A, Aninowu, Davies SC, Brozovic M. Mortality in sickle cell disease: the experience of a British centre. 7 Clin Pathol 1991:44:459-63.

Franklin IM. Services for sickle cell disease: unified approach needed. BM7 1988;296:592.

5 Department of Health and Social Security. Screening and counselling for sickle cell and thalassaemic diseases. London: DHSS, 1988. (EL (88)P92.)

6 Gaston MH, Verter JI, Woods G, Pegelow C, Kelleher J, Presbury G, et al. Prophylaxis with oral penicillin in children with sickle cell anaemia: a randomised trial. $N$ Engl f Med 1986;314: $1593-9$

Vichinsky E, Hurst D, Earles A, Kleman K, Lubin B. Newborn screening for sickle cell disease: effect on mortality. Pediatrics 1988;81:749-55.

8 Prashar U, Aninowu E, Brozovic M. Sickle cell anaemia - who cares? A survey of screening and counselling facilities in England. London: Runnymede Trust, 1985.

9 Smith I, Cook B, Beasley M. Review of neonatal screening programme for phenylketonuria. BMF 1991;303:333-5.

10 Tsevat J, Wong JB, Pauker SG, Steinberg MH. Neonatal screening for sickle cell disease: a cost-effectiveness analysis. F Pediatr 1991;118:546-54.

11 Lane PA, Eckman JR. Cost-effectiveness of neonatal screening for sickle cell disease. $\mathcal{J}$ Pediatr 1992;120:162-3.

12 Horn MEC, Dick MC, Frost B, Davis LR, Bellingham AJ, Stroud CE, et al. Neonatal screening for sickle cell disease in Camberwell: results and recommendations for a two year pilot study. $B M F$ 1986;292:737-40.

13 Milne RIG. Assessment of care of children with sickle cell disease: implications for neonatal screening programmes. BM7 1990;300:371-3.

14 Smith R. Using a mock trial to make a difficult clinical decision. $B M \mathcal{F} 1992 ; 305: 1284-7$.

15 Davies SC. The vaso-occlusive crisis of sickle cell disease, $B M \mathcal{F}$ 1991:302:1551-2.

16 Sergeant GR. Sickle cell disease. 2nd ed. Oxford: Oxford University Press, 1992.

16 Sergeant GR. Sickle cell disease. 2nd ed. Oxford: Oxford University Press, 1992. London: DoH, 1991. (Press release H91/627.)

\section{At last a strategy for British science}

\section{A lost opportunity}

Margaret Thatcher was deeply unpopular in the scientific community. The first prime minister for decades to hold a science degree, she provided no leadership for science, squeezed its funding at a time when remarkable new scientific vistas were opening up, and allowed Britain to slip towards the second division of science. When John Major took over and gave a cabinet minister, William Waldegrave, responsibility for science the expectations of scientists were raised. They were raised still further when $\mathrm{Mr}$ Waldegrave promised a fundamental review of science strategy. At last Britain was going to get serious about science.

Against this background, the publication of the strategy ${ }^{1}$ last week was a great disappointment (p 1498). ${ }^{2}$ There is no feeling of vision, leadership, passion, or commitment; no mechanism for handing real power to the scientists themselves; and no clear sense of how British science will move forward. It consists mainly of a rearranging of committees that are remote from the scientists.

What's wrong with British science? The diagnosis of the white paper seems about right: the British are good at science but poor at benefiting from the results; government objectives for science are unclear and sometimes contradictory; the broader culture doesn't value science, and much of the population, including most politicians and senior civil servants are woefully ignorant of science; the management of science is poor; and the career structure of scientists is a mess. The white paper might have added that government commitment to science seems ambivalent; that science is underfunded; and that too much of Britain's spending on science is on defence research.

Britain's first requirement is for a government completely committed to science, with a clear vision of what it wants from science. The white paper contains some of the rhetoric, but there is still no cabinet minister who concentrates on science alone. Mr Waldegrave is also reforming the civil service and implementing the citizen's charter, and on the day that his grand strategy for science was published media attention was focused more on whether he would be removed from the government than on his white paper. Then, there is no promise of more money, no attack on the waste of defence research, and no real incentive for industry to invest more in research and development.

Nor is it easy to see how the rearrangement of the central committees will improve the management of science. The Advisory Council on Science and Technology is to be changed to the Council for Science and Technology. The Advisory Board for the Research Councils, a quasiindependent body that was largely ignored anyway, will be absorbed into the Office of Science and Technology within $\mathrm{Mr}$ Waldegrave's department, and a new post of director general of research councils will be created. These changes suggest less independence and more direction.

The Science and Engineering Council is to be split into two councils, and the Agricultural and Food Research Council is to be changed to the Biotechnology and Biological Sciences Research Council. The research councils are all to be given a mission statement that makes explicit their commitment to wealth creation and quality of life. In future they will have a part time chairperson, a full time chief executive, and a slimmed down council.

For the Medical Research Council, this essentially amounts to business as usual, and it's hard to see that these changes at the top of the science pyramid will make much difference at all. The white paper quotes Sir Michael Atiyah, president of the Royal Society, that "too much stress on organisational structures may obscure the basic fact that progress in science depends on the ideas, inspiration, and dedication of individual scientists, not the machinations of councils, committees, and departments"-and then it seems largely to ignore his message. Nor does the white paper pay any attention to the management within the councils despite evidence that it may be outdated and top heavy. The $B M \mathcal{F}$ will return to this theme in a fortnight's time.

Every white paper must have some new rabbit to pull out of the hat, and the rabbit in this one is technology foresight. This is a process, highly developed in Japan, of systematically collecting the opinions of researchers, industrialists, and others on what science might produce and the market might need. Areas of science and technology ripe for development are thus identified, and the information is used to direct 